\title{
THE BAPTISMAL ANOINTINGS ACCORDING TO THE ANONYMOUS EXPOSITIO OFFICIORUM ${ }^{\dagger}$
}

\author{
SEBASTIAN BROCK \\ UNIVERSITY OF OXFORD \\ ORIENTAL INSTITUTE \\ PUSEY LANE, OXFORD OX1 2LE
}

\section{INTRODUCTION}

The extensive anonymous commentary, wrongly ascribed by Assemani to George of Arbela, is one of the most important sources of information on the development of the East Syriac liturgical tradition and seems to date sometime between the seventh and ninth century. ${ }^{1}$ At many points the author directly quotes the liturgical reformer Isho'yahb III himself.

† Originally published in G. Karukaparampil (ed.), Tuvaik: Studies in Honour of Rev. Jacob Vellian (Syrian Churches Series 16; Kottayam, 1995) 27-37, and reproduced here by kind permission of the editor. (The volume is available from Madnaha Theological Institute, Thellakam P.O., Kottayam 16, Kerala.)

${ }^{1}$ Ed. R.H. Connolly, Anonymi auctoris expositio officiorum ecclesiae Georgio Arbelensi vulgo ascripta, I-II (CSCO 64, 71, 72, 76; Scr. Syri 25, 28, 29, 32; 1911-15). Memra V on baptism features in volume II, pp. 105-9 (text); this section is reproduced, with an accompanying Arabic translation, by J. Isaac, in Bayn an-Nabrayn 11 (1983): 329-80.

The Commentary on the baptismal rite by Timothy II draws on the Anonymous Commentator at a few points; see the edition and translation 
Book $\mathrm{V}$ is devoted to the baptismal liturgy, and the fifth chapter of this specifically concerns the anointings. In this chapter the author offers a very interesting-and at the same time idiosyncratic-interpretation of the significance of the four different points at which oil was originally used in the East Syriac baptismal rite, ${ }^{2}$ namely at the rsoi, or 'marking, signing', at the rhavers, or 'anointing', the pouring of oil on the baptismal water at its consecration, and the post-baptismal scsiaw, or 'sealing'.

In this present contribution, I offer an English translation of this chapter, together with some comments. First, however, some introductory remarks should be made concerning the anointings in the Syriac baptismal tradition as a whole.

The various Syriac baptismal rites are well known to liturgists for their profusion of anointings. In both East and West Syriac rites $^{3}$ we normally encounter three anointings of the baptismal candidates, each originally distinguished by a different term, thus:

(1) Before the sanctifying of the water there is the ssroi, or 'marking, signing', when the forehead is 'marked' with the sign of the cross.

(2) After the water has been sanctified, and immediately before the baptism, there is the /Lمسمس, or 'anointing', where the whole body is anointed. ${ }^{4}$

(3) After the baptism there is the rof, 'imprint', 5 or sstiow, 'sealing', involving the organs of sense, or just the forehead.

by P.B. Kadicheeni, The Mystery of Baptism (Bangalore, 1980), especially section 19 (pp. 88-93).

${ }^{2}$ See notes 7-9.

${ }^{3}$ For the West Syriac rites, see my "Studies in the early history of the Syrian Orthodox baptismal liturgy", Journal of Theological Studies ns 23 (1972): 16-64, esp. pp. 22-40; and, in general, my The Holy Spirit in the Syrian Baptismal Tradition (Syrian Churches Series 9, ed. J. Vellian; 1979).

${ }_{4}^{4}$ This is absent from the West Syriac 'Tagrit' rite, which is used in India.

${ }^{5}$ This is the term used in the West Syriac tradition, where the verb $\mathrm{htm}$ is used for the signing of the candiates without oil connected with the inscription of the candidates names (the anonymous commentator covers this in his chapter 2, but he does not mention specifically any signing). 
In addition, oil (myron in the West Syriac tradition) is poured on the water in the course of the prayer sanctifying the water.

The origin and development of these different anointings is not our concern ${ }^{6}$ here, where discussion is confined to the anonymous commentator's account. The baptismal service that this account describes is basically the same as that still in use in the Church of the East, and will go back to the liturgical reforms of Ishoyahb III in the mid seventh century. Before turning to the anonymous author's account of the anointings it will be helpful to summarize the situation in current usage in the Church of the East. ${ }^{7}$ In this rite oil is connected with four different elements in the service; these are designated A, B, C, D below, and they are listed in the sequence in which the oil impinges on the candidate:

A - the first of the two pre-baptismal anointings (

$\mathrm{B}$ - the second pre-baptismal anointing (Rtiours).

$\mathrm{C}$ - the pouring of oil on the sanctified waters in which the candidates are baptized.

$\mathrm{D}$ - the post-baptismal anointing (sostiow).

It is essential to note that two different sources of oil are involved: (1) the oil in 'the horn of anointing'

${ }^{6}$ On this see especially G. Winkler, "The history of the Syriac prebaptismal anointing in the light of the earliest Armenian sources", II Symposium Syriacum (OCA 205; 1978) 317-24, and "The original meaning of the pre-baptismal anointing and its implications", Worship 52 (1978): 24 45; also S. Brock, "The Syriac baptismal ordines with special reference to the anointings", Studia Liturgica 12 (1977): 177-83, and "The transition to a post-baptismal anointing in the Antiochene rite", in B. Spinks (ed.), The Sacrifice of Praise: Studies in honour of A.H. Couratin (Ephemerides Liturgicae, Subsidia 19; 1981) 215-25.

${ }^{7}$ An English translation can be found in K.A. Paul and G. Mooken, The Liturgy of the Holy Apostles Adai and Mari... and the Order of Baptism (Trichur, 1967) 117-73 (there are also older English translations by G. Badger (1852) and the Archbishop of Canterbury's Mission to the Assyrian Church of the East (1893). In both the Chaldean and the restored Syro-Malabar rites there are a number of differences, but these are not our concern here; for the latter, see J. Madey and G. Vavanikunnel, Taufe, Firmung und Busse in den Kirchen des Ostsyrischen Ritenkreises (Einsiedeln, 1971) 85-119, and F. Chirayath, Taufliturgie des Syro-Malabarischen Ritus (Das östliche Christentum, nF 32; 1981) 78-103. 
(مhauess (مi), which is already sanctified — and so provides the element of continuity; and (2) the oil in the bowl or flagon (لمع/), which is sanctified in the course of the service. The oil from the horn is used for the first and the last anointings (A and D), and it is also poured on the water $(\mathrm{C})$; the oil in the bowl, however, is used only for the anointing immediately before the baptism (B). References to these four different ways in which oil is used occur in the following sequence in the course of the rite:

A - the verb used in the formula spoken by the priest is prids; the oil is specified as being from the horn, and the priest applies it with his index finger. (Some manuscripts and printed texts of the rite do not specify the use of oil here at all, ${ }^{8}$ and Diettrich ${ }^{9}$ thought that the absence of oil represented the original situation, but this is unlikely in view of the early testimony of the anonymous commentator).

B(i) - unblessed oil is poured into a bowl (لمع and the priest then recites a special prayer of sanctification, which includes an epiclesis.

B(ii) - the priest 'signs' (خغ i) the oil in the bowl with the oil in the horn with the sign of the cross.

$\mathrm{C}(\mathrm{i})$ - after the prayer sanctifying the water (which also contains an epiclesis), the priest takes the horn of anointing and 'signs' (iان (i) the water, pouring in drops in the form of a cross.

B(iii) - the baptismal candidates are anointed with oil from the bowl. The accompanying formula varies in the manuscripts, ${ }^{10}$ with either ' $\mathrm{N}$ is signed (דrids)', or ' $\mathrm{N}$ is anointed (urshs)'; the latter will certainly be the original.

$\mathrm{C}(\mathrm{ii})$ - the candidates are baptized in the water on to which some of the oil from the horn has been poured $(=\mathrm{C}(\mathrm{i}))$.

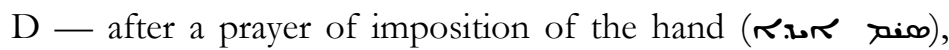
the priest 'signs' (i் i) on the head all those that have been baptized, and then takes the horn of oil and signs their

8 See G. Diettrich, Die nestorianische Taufliturgie (Giessen, 1903) 61; Chirayath, Taufliturgie des Syro-Malabarischen Ritus, 39 with notes 263-4.

${ }^{9}$ Diettrich, Die nestorianische Taufliturgie, 8, note 4, and p. 62.

${ }^{10}$ See Diettrich, Die nestorianische Taufliturgie, 77. 
forehead with the thumb of his right hand. (As with A, there is again variation in the manuscripts and editions, with some omitting all reference to oil). ${ }^{11}$

The style of our anonymous author is often terse and obscure, and R.H. Connolly, who translated the text into Latin to accompany his edition in CSCO, commented:12 'the author's tumultuous style, which often goes against the rules of grammar, prevents any attempt at a word for word translation'. In my translation below I have tried to clarify the author's cramped style somewhat, and words added by me to help the sense have been placed in brackets. For ease of reference, section numbers have been introduced; also, to assist understanding, I have added headings to each section and, where applicable, the corresponding place in the schema, A-D, set out above. Since the end of chapter 4 is also of relevance, a translation of this is included.

\section{TRANSLATION}

\section{[End of chapter 4; p. 104] (The horn of oil represents the Holy Spirit)}

Thus now too he indicated by means of the horn (of oil) that which took place in (the time of) the Law, for by (the horn) the New (Covenant) is perfected. (For) he places the horn in the role (lit. position) of the Holy Spirit: when (the Spirit) anointed priests, they established the priesthood; and when (the Spirit) anointed kings, they established kingship. And it is the one Spirit who performs all these things, [p. 105] allocating and distributing as she wishes, not being manifested as opposed to a single one of (these) activities. And now, in the case of the signing ( candidates, the (horn of oil) takes the place of Abraham's circumcision and the promise (made) to him.

11 See Diettrich, Die nestorianische Taufliturgie, 48, 84-5; Chirayath, Taufliturgie des Syro-Malabarischen Ritus, 58-9; and the discussion in A. Raes, "Ou se trouve la confirmation dans le rite syro-orientale?", L'Orient Syrien 1 (1956): 239-54, and in W. de Vries, Sakramententheologie bei den Nestorianern (OCA 133; 1947) 182-9.

12 Turbidus auctoris stylus, qui saepe contra grammaticam peccat, impedivit ne verbum pro verbo reddere tentaremus, CSCO 76, Scr. Syri 32, p. 3. 


\section{Chapter 5}

[10] 1. (The problem stated)

Concerning (the reason) why, since we make the rsroi and anoint and baptize and seal from a single horn (of oil), we do not (just) do this using it once, but rather, four times. And if the oil in the horn is holy, why is it necessary for the priest to sanctify another lot of oil, and likewise (with) the baptismal water: when the Spirit descends on the water, why does it need to be signed from the horn?

[11] 2. (The unity of the Spirit's activity in the two Testaments)

As we have said before, the horn corresponds typologically to the horn in the Old Testament, which partook of the power of the Spirit-for we do not say that the things in the Law were not guided by the power of the Holy Spirit; rather, it is a single God who was with Moses in the oneness of his nature, but who is now (known to us) in his trinity of persons (مستحك)), (this same God) having manifested in the Old Testament types of the New, in that God, being Creator and one, was manifested as causing the Holy Spirit to act, and not with the Spirit existing and acting apart from the will of God; nor (is the Spirit there depicted) as not fulfilling the will of God, for the Spirit who intimated through the prophets was God, and was named 'Lord.'

[12] 3. (The role of John the Baptist)

Accordingly now John, wanting to fulfil the Old Testament, took the horn of oil from the (prophets) and placed it as a foundation in his own baptismal (rite), (thus) demonstrating that "I have not preached (anything) that is outside the truth to which you hold; and, myself still being within the old laws, I take from them strength so as to preach this covenant". So, when the Pharisees asked him, "Who are you?", he confessed, "I am the voice which calls [p. 106] in the wilderness, just as the prophet Isaiah said" (John 1:23).

[13] 4. (The four dispensations symbolized by the horn of oil)

The four dispensations ( horn are as follows: the dispensation of the beginning of the Old (Testament), and the latter part of its dispensation; and the beginning of the dispensation of the New (Testament) that (came) through John, and the dispensation which is in Christ. 
[14] 5. (The signing, مrai [= A])

The first signing is the one with which Abraham was signed by God, so that this signing is therefore on the forehead, indicating that it was from his (sc. Abraham's) seed that the One who would bless the peoples on their foreheads would come forth. And this signing (Rscai) is equivalent to the sealing (astion [= D]). The fact that (the priest) signs (i) with one finger (is) because the power of God has not (yet) been revealed over us, and (so) we have not been able to recognize it except in part.

[15] 6. (The anointing, Rhauess[= B(iii)])

The anointing of the baptized is the one which took place through Aaron and his sons, and the kings (of Israel).

[16] 7. (The baptism [= C(ii)])

The baptism in the 'Jordan' (i.e. font) is the baptism of John, for the forgiveness of sins.

[17] 8. (The sealing, sostiow [= D])

The final sealing (is) the baptism of our Lord, which is fulfilment in the Holy Spirit.

[18] 9. (Further on the signing [= A $]$ )

Therefore the first signing is signed from the horn without any (accompanying) labour (i.e. special prayers), for likewise the promise (made) to Abraham took place without the labour of the laws, and he believed in God by word alone, and this was considered as righteousness in his case (Rom. 4:3).

[19] 10. (Further on the anointing [ $=\mathrm{B}(\mathrm{i}, \mathrm{ii})]$ )

The anointing which takes place by means of prayers and consecratory (acts is) because thus Aaron too was supplicating with insistent prayers on behalf of the people, and offering up various kinds of offerings, so that the people might acquire forgiveness.

[20] 11. (The pouring of oil on the water $[=\mathrm{C}(\mathrm{i})]$ )

The fact that in the middle of the consecratory prayer (for the water) the priest signs (i i i the oil and then comes to the 'Jordan' (i.e. font), is because John stood in the midst, between the two Testaments, for he fulfils the Old and the New, in that he observed both laws. 
[21] 12. (The absence of an epiclesis over the oil in the horn)

The fact that the Spirit does not descend upon the oil (in the horn) is because perfection was not granted in the Old (Testament).

[22] 13. (The oil in the bowl, however, is consecrated)

The fact that (the priest) does not leave the (other) oil in the bowl without consecration is because, when the (Old Testament) priests too approached to be anointed, first of all prayer and sacrifice was also offered up on their behalf, and (only) then [p. 107] would they be anointed.

[23] 14. (A further reason why there is no epiclesis over the oil in the horn)

The fact that the Spirit does not descend is because they (sc. the Old Testament priests) have not (yet) acquired perfection.

[24] 15. (The meeting of the two laws)

The fact that (the priest) turns towards the 'Jordan' is because he has turned from (one) law to (another) law.

[25] 16. (The horn is a sign of continuity from the Old Testament)

The fact that the horn comes with him is because he has not caused innovations to spring up.

[26] 17. (The reason for the epiklesis over the water)

The fact that the Spirit descends over the water is because today there has occurred the complete consecration, in the baptism of John.

[27] 18. (The relationship between the oil in the bowl and the oil in the horn $[=\mathrm{B}(\mathrm{ii})])$

(The priest's) signing the oil (in the bowl) which is being sanctified (with oil) from the horn is because, even though the (Old Testament priests) were sanctified by means of sacrifices, nevertheless they were not perfected without the power of God.

[28] 19. (The pouring of oil on the water [ $=\mathrm{C}(\mathrm{i})]$ )

(The priest's) signing the water using the horn is in order to unite the Old Testament and the New; just as, when our Lord delineated eyes for the man blind from his mother's womb, he sent him to Shiloh (John 9:7), which belongs to the Old (Testament), 
indicating that he was not distancing himself from their Law; so too John (who symbolizes the priest), when sanctifying the 'Jordan', indicates its sealing (to be) by means of the Spirit who ministered to the Old (Testament).

[29] 20. (Why the deacon, rather than the priest, does the anointing)

The fact that the priest who is baptizing does not do the anointing is because he is showing that the anointing belongs to the Old (Testament), and the priests who belong to the Old (Testament) should perform what pertains to the Old (Testament). ${ }^{13}$

[30] 21. (Why the priest alone baptizes)

The fact that (the priest) comes and baptizes alone, having himself sanctified the oil, is because he is indicating that "even though I have acted through the Old (Testament), nevertheless I am (engaged) in something which is greater than that".

22. (The fourfold experience of the baptismal candidates)

The fact that all these things pass over the baptized-I mean the type of Abraham and the type of Aaron-is because they cannot become heirs of the Kingdom and become (Abraham's) children unless they begin with his way of life, seeing that John said to them "God is able to raise up children for Abraham even from these stones" (Matt. 3:9)—that is, from the gentiles. And the baptismal candidates now become children of Abraham by means of the promise $[=A]$, and companions of Moses by means of matters pertaining to the Law $[=\mathrm{B}]$, and they are (next) baptized with the baptism of John $[=\mathrm{C}]$; and then they are perfected with the baptism of our Lord [= D].

[32] 23. (The four types in baptism)

These, then, are the four types in baptism, namely (represented in) the signing (مsrai), the anointing (Rhauers), the baptism

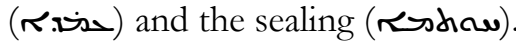

13 I.e. the deacons do the anointing instead. The commentator evidently has in mind the Levitical character of the Old Testament priesthood, and the association, frequent in early Christian literature, of Levites and deacons. 
24. (The correspondence between the rseai $[=\mathrm{A}]$ and the ostion [= D])

The fact that (the baptism) of our Lord (i.e. the rstiow) is equivalent to that of Abraham, (but) is different from that of Aaron and that of John, (is) because Christ too is son of David, son of Abraham, whereas he was not a son of Aaron; for he is showing that this sealing (is the one) whose [p.108] beginning took place through the promise to Abraham. And the demonstration (can be seen) from the resemblance of the two of them: in the first, the priest says "is signed", but now finally, "he has been baptized and is perfected". But look at the wording: first, "is signed", and this only on the forehead; then, "is anointed", in this case, the whole body. But the signing, serving as an indication of the promise, is signed just on the forehead.

[34] 25. (The correspondence between the anointing [= B] and the baptism $[=\mathrm{C}]$ )

For the anointing, corresponding to the priests and kings being anointed, (the deacon) anoints the whole body; (likewise) for the baptism, in that John baptized the whole person, (the priest) baptizes the whole body in the water.

26. (The significance of the threefold immersion at the baptism [= C(ii)])

But take a look too: in the signing and anointing, even though he says the words "is signed..." [= A] and "is anointed..." [= B], nevertheless he does not indicate this in what he actually does, as (in the case of) the baptism [= C(ii)]: for he says " $\mathrm{N}$ is signed" and "is anointed" "in the name of the Father, Son and Spirit", but it is not the case that, along with saying this, he carries it out (by signing or anointing three times). Just as is the case when, even though God manifested a type of the threefold character of his Persons (مستحك) in the Old (Testament), nevertheless he did not bring these types to perfection. (Accordingly) now here at the baptism, along with "is baptized"-in the name of the Trinity-he also baptizes (or, submerges) (the candidate) three times. (Thus) he indicates the name (of the three Persons) and he (also) completes the action in actual practice.

[36] 27. (The significance of the sealing [D])

At the sealing, in that the Spirit descends, resembling tongues of fire (cf Acts 2:3), and actually settles on each one of them, (the 
priest) makes the sealing on the top of the face, making it resemble that promise (made) to Abraham.

28. (Why the four actions are kept separate)

It is for these reasons that he signs, anoints, baptizes and seals from the single horn. The fact that he does not carry all these (actions) out together in one place is because all the actions (in the Old Testament which they signify) were not carried out together, but at each (specific) time the Spirit brought (each individual) one of them to completion, (namely), at the time of the promise, and at the time of the fleshly instructions, and at the time of the baptism with water-but elsewhere (at the time of) the baptism with the Spirit.

[38] 29. (A reply to those who object to Old Testament typology)

But [p. 109] there are some people who say that the Old (Testament) is not symbolized in the Church's ministry. But we should say to them (in response): 'Our Lord said, "I have not come to undo the Law or the prophets, but to fulfil it" (Matt. 5:17). And if these have not been dissolved, (Christ) shows their fulfilment, (using) them in actual practice. Just as he fulfilled everything in the Law, so too both in the case of the baptized, and in the case of all our services, these begin in symbol with creation and (extend) to our resurrection from the dead.

\section{Discussion}

[39] The passage contains many puzzling features and deserves a detail commentary, but here only a few salient features can be noted. In the first place it is significant that the three anointings are still identified by the use of the three different terms, sscai, rhouers, rastion.

The anonymous author sees the baptismal rite as a chronological progress through salvation history in four

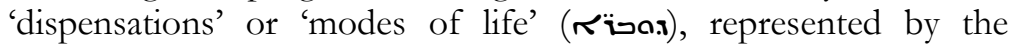
'signing', the 'anointing', the baptism, and the 'sealing' (i.e. A-D); the first two dispensations belong to the Old Testament, and the last two to the New, while the horn of oil (representing the Holy Spirit) provides the continuum.

[41] Thus we have the following associations for the four stages, A-D: 
A - the promise of Abraham $(5,9)$. The end of chapter IV specifically mentions the connection seen between the rsrai and Abraham's circumcision, a link which can be traced back to the earliest roots of the Syriac baptismal tradition. ${ }^{14}$ This stage also represents the time before the giving of the Law (9), and this is given as a reason why there is no need to sanctify the oil specially here.

$\mathrm{B}$ - the anointing of priests (Aaron) and kings $(6,10)$. Since the Old Testament anointing was accompanied by prayers and offerings (i.e. was subject to the ordinances of the Law), there is need to sanctify oil (that in the bowl) specially for this anointing.

C - the baptism is associated with the baptism of John.

$\mathrm{D}$ - the post-baptismal anointing is associated with the baptism of Christ.

[42] While parallels to the interpretations of A and B can readily be found in earlier literature, the understandings given to $\mathrm{C}$ and $\mathrm{D}$ are surprising; presumably the baptism is seen as primarily providing forgiveness, and the post-baptismal anointing as conferring the benefits brought by Christ. Elsewhere in this Memra the anonymous commentator is anxious to disassociate Christian baptism from the baptism of Christ in the Jordan. It is evident that he is following Isho yahb III on this, for in chapter 1 of Book V the commentator describes how Isho'yahb was anxious to dissociate the Christian baptismal rite from the baptism of Jesus by placing it at Easter, rather than at Epiphany.

Although the four dispensations provide a clear chronological progression, they are at the same time elaborately interlocked, in a variety of different combinations; thus we have:

- The Old Testament (= A, B) is linked to the New (= C, D) by John the Baptist who looks both ways (11), and by the horn (19; ср 16).

- At the same time the Old Testament is dissociated from the New by a number of features $(20,21,22)$, and its imperfection is emphasises on various occasions $(18,24,26)$.

${ }^{14}$ See Brock, The Holy Spirit in the Syrian Baptismal Tradition, 97-8. 
- B (the second anointing) and C (the baptism) are linked together since both involve the whole body (25).

- A (the first anointing) and D (the post-baptismal anointing) are doubly linked: they both involve the forehead (27), and because Christ is a descendant of Abraham, rather than of Aaron (24). The association of these two anointings is of course historically correct, since the post-baptismal anointing, originally absent from the Syrian rite, took over (and at the same time, expanded on) the main symbolic meanings of the pre-baptismal rseai.

[44] The various different relationships between the four occurrences of the use of oil and their biblical antecedents can be expressed diagrammatically as follows:

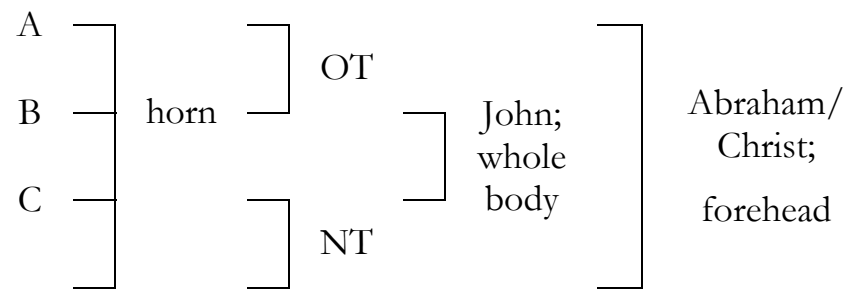

[45] Finally, we may note that in chapter 2 of the anonymous commentator's Memrā V, on Baptism, ${ }^{15}$ the author hints at the chief rationale underlying all Isho'yahb's liturgical reforms, saying that 'this blessed man (sc. Isho'yahb III) was eager to depict in all the (different) services a delineation of (both) the Old and the New (Testaments)'. This suggests that the basic inspiration for the commentator's interpretation of the baptismal anointings in fact may go back to Isho'yahb himself.

15 Text, p. 96. 
